Brit. J. vener. Dis. (1960), 36, 59.

\title{
OBITUARY
}

\section{GERALD HOWARD KNIGHT}

Dr. Gerald Howard Knight died suddenly on January 23, 1960. He was educated at King Edward's School and the University of Birmingham, where he graduated M.B., Ch.B. in 1928 and proceeded M.D. in 1931. He had a distinguished career as an undergraduate, winning the Fenwick Scholarship and the Gold Medal in Clinical Medicine and Surgery.

After holding resident posts for over 2 years at the General Hospital, Birmingham, he was appointed to the staff of the venereal diseases' department and in 1952 succeeded Dr. Assinder as Senior Consultant and Lecturer in Venereology to the University of Birmingham.

Dr. Knight was an outstanding physician whose opinion was eagerly sought not only in regard to his specialty, but also concerning life assurance work in which he was an expert. During the war years he was one of a small band of men who did invaluable work for the Blood Transfusion Service. Dr. Knight was on the Council of the M.S.S.V.D. and on the Committees of the B.M.A. Venereologists' Group and of the British Co-operative Clinical Group. In all these bodies his opinion, based on wide experience and much innate wisdom, was highly valued. His counsel will be missed, as will his quiet but good-humoured and cheerful personality.

He was a keen sportsman. In his younger days he played full back for the Old Edwardians and for his University. He was also a tennis and cricket enthusiast. For a number of years he was chairman of the Newton Tennis Club and had recently been appointed to the Warwickshire Committee of the Lawn Tennis Association.

Dr. Knight was a delightful host and had a very happy home life. He leaves a wife and three children to whom our deepest sympathies go out. W.F. 